\title{
Retention Profile of Mercury (II) Ions from Aqueous Solution onto Some Selected Local Solid Sorbents
}

\author{
Khairia M. Al-Ahmary and Mofida W. Essa ${ }^{1}$ \\ Department of Chemistry, Girls College of Education, \\ King Abdulaziz University Jeddah, KSA \\ 1. Nuclear Research Center, Radiation Protection Department, \\ Cairo, Egypt
}

\begin{abstract}
The influence of different parameters e.g. contact time, $\mathrm{pH}$, sorbent doze and competing ions that control the retention profile of mercury (II) from aqueous solution, onto some selected local soil solid sorbents collected from Saudi Arabia, as solid scavenger of heavy metals released from environment, was critically investigated. The uptake of mercury (II) species onto the employed solid sorbent was found fast and followed a first-order rate equation. The sorption data of mercury (II) onto the solid sorbents followed Freundlich type sorption isotherm. Thus, sorption mechanism involving "surface adsorption" mechanism seems a more likely retention model. The cellular structure of the PUFs sorbent offer unique advantages over conventional bulk type sorbents in rapid, versatile effective separation and/or pre-concentration of gold ions. The proposed solid sorbent could be packed in column mode for quantitative collection of trace and ultra trace mercury (II) concentration from different water including wastewater.
\end{abstract}

Keywords: Mercury (II) ions, aqueous solution, adsorption, local soil samples, AAS.

\section{Introduction}

Natural substances such as clay minerals, local soil and active carbon, artificial such as organic compound and synthetic polymers have been reported as excellent sorbents for trace metals ions ${ }^{[1-5]}$. The sorption behavior of heavy metals and their differential determination employing c18-bonded silica as the column material and silica gel surface 
immobilized with zirconium (IV) and zirconium (VI) phosphate have been studied ${ }^{[2-5]}$. The Determination of mercury (II) at trace levels in welding fumes employing a strong anion-exchange containing hydrophilic polyether resin substituted with quaternary amine groups has been reported ${ }^{[6]}$. The chemical speciation and determination of trace of metal ions present in aqueous solution employing solid extractors such as an adsorbent in column mode has been performed ${ }^{[7-9]}$.

Recent years have seen an upsurge of interest on the removal, separation followed by subsequent determination of mercury (II) ions in aqueous media because, of its toxicological importance in ecosystems, agriculture and human health ${ }^{[10]}$. Few studies have been conducted to characterize the metal content in different substrates: Soil, air, food, water, paints, dust, teeth and others ${ }^{[10]}$. On the other hand, the study of mercury content in soil has a great importance due to the fact that soils effectively act as a reservoir which, after temporary storage of metals, can act as a source under certain conditions. Therefore, soil is considered to be both a source and sink for metal pollutants. The factors controlling the total and bioavailability concentration of mercury in soil is of great importance for human toxicology and agricultural productivity ${ }^{[1]}$.

Various methods have been studied for removal of heavy metals from industrial effluents including precipitation (and sludge separation), chemical oxidation (or reduction), ion exchange, reverse osmosis, membrane separation, electrochemical treatment and evaporation ${ }^{[12,13]}$. Sorption processes are relatively easy to apply, but typically the cost of the sorbent is prohibitive. Several studies have focused on the development of an economical and effective sorbent for heavy metals ${ }^{[14-16]}$. Adsorption by inorganic adsorbents is a promising technique for the purpose of metals remova ${ }^{[17]}$. The present work, studied the adsorption behavior of mercury by the soil as a function of contact time, metal concentration, $\mathrm{pH}$ and competing ions.

The present manuscript describes low cost procedures for the extraction, pre concentration and sequential photometric determination of mercury (II) in water samples. The proposed method is based upon the retention of mercury (II) onto the used local soil after treatment. Optimum experimental conditions were investigated with respect to a standard solution of the same matrix, in order to examine the possibility of obtaining the maximum extraction efficiency with minor sample 
treatment and minimal experimental conditions. The method is convenient for the chemical separation of mercury (II) in water. The Freundlich adsorption model will be employed for assigning the sorption step of random distribution sites of energy in the solid sorbent used.

\section{Experimental}

\section{Reagents and Materials}

All chemicals used were of analytical reagent grade. Doubly deionized water was used throughout. BDH reagent 5-(2-benzothiazolylazo)-8-hydroxyquinoline solution $(0.1 \% \mathrm{w} / \mathrm{v})$ was prepared by dissolving the required weight in acetone. Stock solution of mercury (II) ions $(1 \mathrm{mg} / \mathrm{mL})$ was prepared in water. Stock solutions of the competitive ions were prepared in distilled water. Mercury (II) ions were determined by the method reported earlier ${ }^{[18]}$.

All containers used were pre-cleaned by soaking in nitric acid $(20 \%$ $\mathrm{w} / \mathrm{v}$ ) and rinsed with de-ionized water before use.

\section{Apparatus}

A Varian model AA-875 atomic absorption spectrometer (AAS) was used at the optimum conditions of chromium determination. The absorbance of the test solutions were measured with a single beam Digital Spectro UV-VIS RS Labomed, spectrophotometer (USA) with quartz cell (10 mm path length). A pH meter model 3305 (JENWAY) and a lab-line Orbital mechanical shaker SO1 (UK) were used for the $\mathrm{pH}$ measurements and for shaking the test solutions in batch experiments, respectively.

\section{Preparation of Soil Samples}

Soil samples were collected from three regions of Kingdom of Saudi Arabia two samples from East region (EQF1, EDGH1), two samples from West region (WMF1, WMF4) and two samples from South region (SKF1, SAF1). Soil samples were taken from the upper $10 \mathrm{~cm}$ of the surface, crushed to size $<100 \mu \mathrm{m}$ in a crushing machine and finally dried at $100^{\circ} \mathrm{C}$ in an oven for more than 24 hours to ensure complete dryness. A $250 \mathrm{~g}$ soil was transferred to 1 liter beaker together with $600 \mathrm{ml}$ 
doubled distilled water, heated and stirred for 5 minutes. The beaker was then left to cool, centrifuge reject the supernal. Repeat this washing process twice, then the soil samples were dried at $100^{\circ} \mathrm{C}$.

\section{Recommended Procedures}

\section{Influence of Adsorbent Doze}

A preliminary experiment was performed, to determine the most suitable ratio between the soil doze and the solution of mercury. In 50 $\mathrm{mL}$ centrifuge tubes, different weights of each soil samples $(25,50,100$, $150,200,250,300 \mathrm{mg}$ ) were accurately weighed and shaken with $25 \mathrm{~mL}$ of $10^{-4} \mathrm{~mol} \mathrm{~L}^{-1}$ of $\mathrm{HgCl}_{2}$ at $\mathrm{pH}=7$ for 24 hours. For each weight triplicate sample were taken and the concentration of mercury was measured spectrophotometrically against reagent blank ${ }^{[18]}$. The amount of mercury (II) remained in the aqueous phase was determined measured spectrophotometrically against a reagent blank ${ }^{[18]}$. The amount of mercury (II) retained on the solid sorbent was determined from the difference between the concentration of mercury (II) solution before $\left(C_{o}\right)$ and after $\left(C_{a}\right)$ shaking with the soil solid sorbent. The amount of mercury (II) retained at equilibrium, $\mathrm{q}_{\mathrm{e}}$, the extraction $(\% E)$ percentage and the distribution ratio $(D)$ of the mercury (II) uptake onto the used solid sorbent were calculated, respectively employing the equations:

$$
\begin{gathered}
q_{e}=\frac{\left(C_{b}-C_{a}\right) \times V}{W} \\
\% E=\frac{(C o-C a)}{C o} \times 100 \\
D=\frac{\% E}{100-\% E} \times \frac{V(m L)}{W(g)}
\end{gathered}
$$

where, $V$ is the sample volume in $\mathrm{mL}$ and $W$ is the weight of the solid sorbent in grams. The $\% \mathrm{E}$ and $\mathrm{D}$ values are the average of three independent measurements and the precision in most cases was within $\pm 2 \%$. 


\section{Effect of Contact Time}

A $300 \mathrm{~mL}$ of $10^{-4} \mathrm{~mol} \mathrm{~L}^{-1}$ of $\mathrm{HgCl}_{2}$ was transferred to the reaction vessel, which is half liter flat bottomed bottle. An accurate weight of 300 $\mathrm{mg}$ of the soil sample was transferred to the reaction vessel. At this moment, $\mathrm{t}=$ zero, the experiment has started. Samples of $3 \mathrm{ml}$ from the suspension were taken at different time intervals centrifuge at $3000 \mathrm{rpm}$ for 10 minutes. Two samples $1 \mathrm{~mL}$ of each, were taken from the solution for determining mercury concentration. These sampling and determination steps were repeated at different time intervals starting from 5 minutes till about 7 days.

\section{Influence of $\mathrm{pH}$}

A $500 \mathrm{mg}$ of soil sample was accurately weighed in a centrifuge tube to which $50 \mathrm{ml}$ of $10^{-4} \mathrm{M} \mathrm{HgCl}_{2}$ solution was added and $\mathrm{pH}$ is adjusted to $\mathrm{pH} 2$ using $\mathrm{HCl}$ and/or $\mathrm{NH}_{4} \mathrm{OH}$ shaking for 24 hours then the tubes were centrifuged for 10 minutes at $3000 \mathrm{rpm}, 1 \mathrm{ml}$ sample was taken from the supernatant solution for determination of mercury concentration with blank and standard. This procedure was repeated with $\mathrm{pH}(4,7,8,10)$. The amount of ion adsorbed per gram soil and the distribution coefficient (D) were calculated.

\section{Effect of Competing Ions}

A $50 \mathrm{~mL}$ of $10^{-4} \mathrm{~mol} \mathrm{~L}^{-1} \mathrm{HgCl}_{2}$ contains $10^{-6} \mathrm{~mol} \mathrm{~L}^{-1}$ solution of magnesium as competing ion was added to $500 \mathrm{mg}$ of soil sample in centrifuge tube shaken for 24 hour centrifuge and the mercury concentration was measured in supernatant solution using A.A.S. the procedure was repeated with different concentration $10^{-5}, 10^{-4}, 10^{-3}$ and $10^{-2}$ of $\mathrm{mol} \mathrm{L}^{-1} \mathrm{HgCl}_{2}$ and $\mathrm{CaCl}_{2}$ as competing ion.

\section{Effect of Mercury (II) Concentration}

A $50 \mathrm{~mL}$ of different mercury concentration $10^{-6}, 10^{-5}, 10^{-4}, 10^{-3}$ and $10^{-2} \mathrm{~mol} \mathrm{~L}^{-1}$ at $\mathrm{pH} 7$ was added to $500 \mathrm{mg}$ of soil. A mercury concentration was measured after 24 hour taken versus reagent blank. 


\section{Results and Discussion}

\section{Influence of DifferentParameters on the Retention of Mercuric (II) Ions}

Preliminary experiments on shaking constant volume of the aqueous solutions containing mercury (II) in aqueous solution with variable weights of each soil sample were carried out. The results indicated that a reasonable extraction percentage of mercury (II) from the aqueous solution was achieved at the solid: solution phase of 1:10 mass (mg, adsorbent): volume of the aqueous solution.

The influence of shaking time on the extraction percentage of mercury (II) ions from the aqueous solutions by the used local solid adsorbents was critically examined. The results obtained are shown in Fig. 1-3. The data revealed that, the amount, percentage and distribution ratio of mercury (II) ions adsorbed from the test aqueous solutions on the used adsorbents increased on increasing the contact time until reach saturation within 20 hours for all soil samples. The curves might be expressed as the sum of two exponential terms and proceeds in two successive steps as follows ${ }^{[19]}$ :
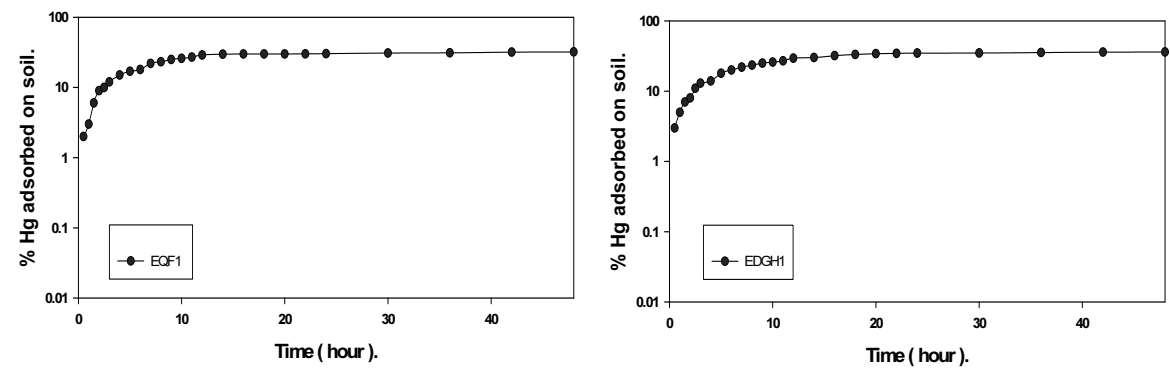

Fig. 1. Influence of time on the retention of mercury (II) ions from the aqueous solution by soil solid sorbents collected from East region.
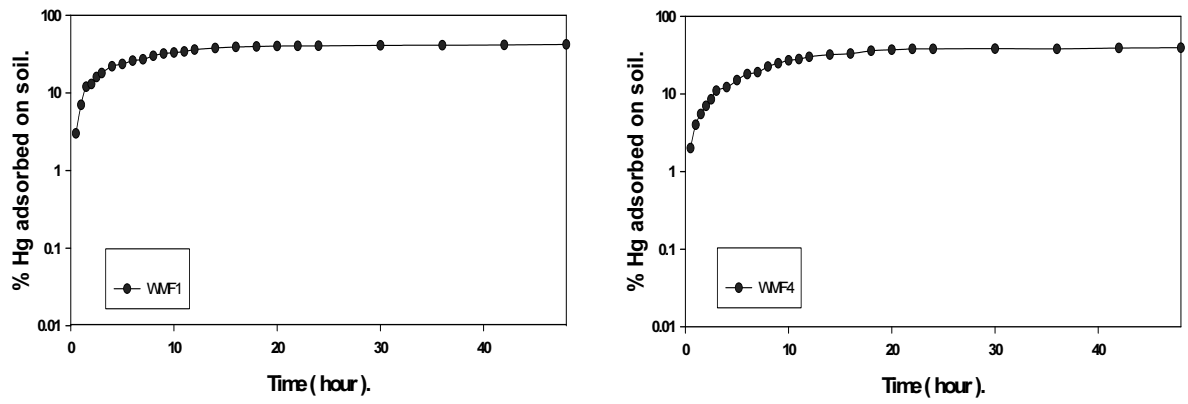

Fig. 2. Influence of time on the retention of mercury (II) ions from the aqueous solution by soil solid sorbents collected from West region. 

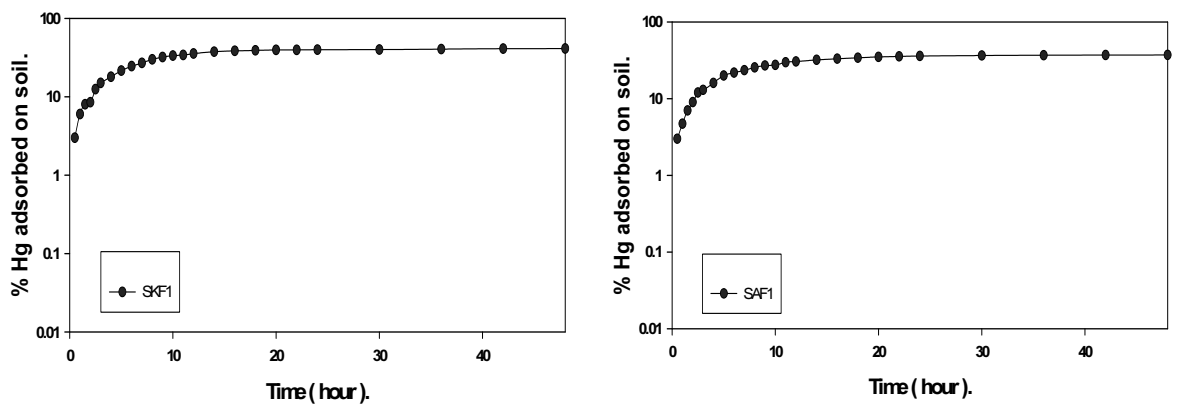

Fig. 3. Influence of time on the retention of mercury (II) ions from the aqueous solution by soil solid sorbents collected from South region.

- In the first step, rapid exchange of ion between the bulk solution and the electric double layer (hydration shell) surrounding the soil crystals is most likely proceeds;

- Second step represents the exchange of ion between the electric double layer and the surface of the solid sorbent with an overall equation as given:

$$
\mathrm{Y}=\mathrm{A}_{1} \mathrm{e}^{-\mathrm{K} 1 \mathrm{t}}+\mathrm{A}_{2} \mathrm{e}^{-\mathrm{K} 2 \mathrm{t}}
$$

where, $A_{1}$ and $A_{2}$ are constants representing the intercept of each component of the curve with the $\mathrm{y}$-axis, and its value gives the compartment size. $\mathrm{K}_{1}$ and $\mathrm{K}_{2}$ are constants representing the slope of each component and its value gives the flow rate between compartments and $\mathrm{t}$ is the time in hours.

The influence of the aqueous solution $\mathrm{pH}$ on the distribution ratio (D) of mercury (II) (in m mol) adsorption by the different soil samples are summarized in Table 1 . In Table 1, it is clear that the amount, $\% \mathrm{E}$ and D of mercury (II) adsorbed from the aqueous solution is not significant at low $\mathrm{pH} 2-6$ due to the competing of $\mathrm{H}^{+}$. At $\mathrm{pH}$ higher than $\mathrm{pH} 6$, the mercury (II) uptake increased slightly upto $\mathrm{pH} 8$ and remained constant.

The effect of competitive ions e.g. $\mathrm{Mg}^{2+}$ and $\mathrm{Ca}^{2+}$ concentrations on the adsorption of mercury (II) ions from the aqueous solutions by soil samples are given in Table 2. It is clear from table that in presence of $\mathrm{Mg}$ and $\mathrm{Ca}$ ions decrease the amount adsorbed of $\mathrm{Hg}$ ion by soil samples and $\mathrm{D}$ values. These results are in agreement with those obtained in previous work $^{[20]}$. 
Table 1. Effect of $\mathrm{pH}$ on the equilibrium adsorption of $\mathrm{Hg}^{2+}$ ions on different soil samples.

\begin{tabular}{|c|c|c|c|c|}
\hline $\begin{array}{l}\text { Samples } \\
\text { code no. }\end{array}$ & pH & $\begin{array}{c}\text { Amount } \\
\text { adsorbed \% }\end{array}$ & $\mathrm{mmol} / \mathrm{g}$ & Kd \\
\hline \multirow{5}{*}{ EQF1 } & 2 & 19 & 0.0019 & 23.46 \\
\hline & 4 & 23 & 0.0023 & 29.87 \\
\hline & 6 & 30 & 0.0030 & 42.86 \\
\hline & 8 & 32 & 0.0032 & 47.06 \\
\hline & 10 & 33 & 0.0033 & 49.25 \\
\hline \multirow{5}{*}{ EDGH1 } & 2 & 21 & 0.0021 & 26.58 \\
\hline & 4 & 25 & 0.0025 & 33.33 \\
\hline & 6 & 31 & 0.0031 & 44.93 \\
\hline & 8 & 32 & 0.0032 & 47.06 \\
\hline & 10 & 33 & 0.0033 & 49.25 \\
\hline \multirow{5}{*}{ WMF1 } & 2 & 25 & 0.0025 & 33.33 \\
\hline & 4 & 29 & 0.0029 & 40.85 \\
\hline & 6 & 40 & 0.0040 & 66.67 \\
\hline & 8 & 43 & 0.0043 & 75.44 \\
\hline & 10 & 45 & 0.0045 & 81.82 \\
\hline \multirow{5}{*}{ WMF4 } & 2 & 24 & 0.0024 & 31.58 \\
\hline & 4 & 31 & 0.0031 & 44.93 \\
\hline & 6 & 38 & 0.0038 & 61.29 \\
\hline & 8 & 40 & 0.0040 & 66.67 \\
\hline & 10 & 41 & 0.0041 & 69.49 \\
\hline \multirow{5}{*}{ SKF1 } & 2 & 33 & 0.0033 & 49.25 \\
\hline & 4 & 37 & 0.0037 & 58.73 \\
\hline & 6 & 40 & 0.0040 & 66.67 \\
\hline & 8 & 41 & 0.0041 & 69.49 \\
\hline & 10 & 41 & 0.0041 & 69.49 \\
\hline \multirow{5}{*}{ SAF1 } & 2 & 27 & 0.0027 & 36.99 \\
\hline & 4 & 30 & 0.0030 & 42.86 \\
\hline & 6 & 36 & 0.0036 & 56.25 \\
\hline & 8 & 37 & 0.0037 & 58.73 \\
\hline & 10 & 40 & 0.0040 & 66.67 \\
\hline
\end{tabular}


Table 2. Influence of competing ions on the mercury (II) ions uptake by the used solid adsorbents.

\begin{tabular}{|c|c|c|c|c|c|c|}
\hline \multirow[b]{2}{*}{ Sample } & \multicolumn{3}{|c|}{ In presence of $\mathrm{Mg}^{2+}$} & \multicolumn{3}{|c|}{ In presence of $\mathrm{Ca}^{2+}$} \\
\hline & $\begin{array}{c}\text { Concentration } \\
\text { of } \mathbf{M g}^{2+} \\
\text { (in } \mathbf{M})\end{array}$ & $\begin{array}{c}\text { Amount } \\
\text { adsorbed of } \\
\mathrm{Hg} \text { (in m } \\
\mathrm{mol} / \mathrm{g})\end{array}$ & Kd & $\begin{array}{c}\text { Concentration of } \\
\mathrm{Ca}^{2+} \\
\text { (in } \mathrm{M})\end{array}$ & $\begin{array}{c}\text { Amount } \\
\text { adsorbed of } \\
\mathrm{Hg} \text { (in } \mathrm{m} \\
\mathrm{mol} / \mathrm{g} \text { ) }\end{array}$ & Kd \\
\hline \multirow{5}{*}{ EQF1 } & $10^{-6}$ & 0.0028 & 38.89 & $10^{-6}$ & 0.0025 & 32.45 \\
\hline & $10^{-5}$ & 0.0024 & 31.58 & $10^{-5}$ & 0.0020 & 25.00 \\
\hline & $10^{-4}$ & 0.0021 & 26.58 & $10^{-4}$ & 0.0017 & 20.48 \\
\hline & $10^{-3}$ & 0.0017 & 20.48 & $10^{-3}$ & 0.0012 & 13.64 \\
\hline & $10^{-2}$ & 0.0014 & 16.28 & $10^{-2}$ & 0.0008 & 8.70 \\
\hline \multirow{5}{*}{ EDGH1 } & $10^{-6}$ & 0.0027 & 36.99 & $10^{-6}$ & 0.0028 & 38.89 \\
\hline & $10^{-5}$ & 0.0024 & 31.58 & $10^{-5}$ & 0.0023 & 29.03 \\
\hline & $10^{-4}$ & 0.0020 & 25.00 & $10^{-4}$ & 0.0018 & 21.95 \\
\hline & $10^{-3}$ & 0.0015 & 17.65 & $10^{-3}$ & 0.0013 & 14.94 \\
\hline & $10^{-2}$ & 0.0011 & 12.36 & $10^{-2}$ & 0.0009 & 9.89 \\
\hline \multirow{5}{*}{ WMF1 } & $10^{-6}$ & 0.0039 & 63.93 & $10^{-6}$ & 0.0035 & 53.85 \\
\hline & $10^{-5}$ & 0.0034 & 51.52 & $10^{-5}$ & 0.0030 & 42.86 \\
\hline & $10^{-4}$ & 0.0032 & 47.06 & $10^{-4}$ & 0.0025 & 33.33 \\
\hline & $10^{-3}$ & 0.0029 & 40.85 & $10^{-3}$ & 0.0020 & 25.00 \\
\hline & $10^{-2}$ & 0.0025 & 33.33 & $10^{-2}$ & 0.0016 & 19.05 \\
\hline \multirow{5}{*}{ WMF4 } & $10^{-6}$ & 0.0033 & 49.25 & $10^{-6}$ & 0.0032 & 47.06 \\
\hline & $10^{-5}$ & 0.0031 & 44.93 & $10^{-5}$ & 0.0027 & 36.05 \\
\hline & $10^{-4}$ & 0.0028 & 38.89 & $10^{-4}$ & 0.0023 & 29.87 \\
\hline & $10^{-3}$ & 0.0024 & 31.58 & $10^{-3}$ & 0.0017 & 20.48 \\
\hline & $10^{-2}$ & 0.0021 & 26.58 & $10^{-2}$ & 0.0013 & 14.94 \\
\hline \multirow{5}{*}{ SKF1 } & $10^{-6}$ & 0.0039 & 63.93 & $10^{-6}$ & 0.0030 & 42.86 \\
\hline & $10^{-5}$ & 0.0037 & 58.73 & $10^{-5}$ & 0.0028 & 38.89 \\
\hline & $10^{-4}$ & 0.0030 & 42.86 & $10^{-4}$ & 0.0025 & 33.33 \\
\hline & $10^{-3}$ & 0.0025 & 33.33 & $10^{-3}$ & 0.0023 & 29.87 \\
\hline & $10^{-2}$ & 0.0019 & 23.46 & $10^{-2}$ & 0.0020 & 25.00 \\
\hline \multirow{5}{*}{ SAF1 } & $10^{-6}$ & 0.0036 & 56.25 & $10^{-6}$ & 0.0032 & 47.06 \\
\hline & $10^{-5}$ & 0.0032 & 47.06 & $10^{-5}$ & 0.0028 & 38.89 \\
\hline & $10^{-4}$ & 0.0029 & 40.89 & $10^{-4}$ & 0.0025 & 33.33 \\
\hline & $10^{-3}$ & 0.0024 & 31.58 & $10^{-3}$ & 0.0020 & 25.00 \\
\hline & $10^{-2}$ & 0.0021 & 26.58 & $10^{-2}$ & 0.0016 & 19.05 \\
\hline
\end{tabular}




\section{Sorption Isotherms}

The sorption profile of mercury (II) ions from the bulk aqueous solution at the optimum $\mathrm{pH}$ onto the used solid adsorbents was determined over a wide range of concentrations $\left(10^{-2}-10^{-6} \mathrm{~mol} \mathrm{~L}-1\right)$. At low or moderate mercury (II) concentration, the amount of mercury (II) adsorbed onto the solid sorbents varies linearly with the corresponding mercury (II) concentration in the aqueous solution suggesting first order behavior. The distribution ratio decreases on increasing mercury (II) concentration as solid membranes become saturated with the adsorbed species rapidly. The most favorable $\mathrm{D}$ values were achieved for more diluted solutions. Thus, intraparticle transport and film diffusion may be the two steps controlling molecular diffusion at the macrospores of the sorbent and the rate of mercury (II) sorption onto the reagent immobilized foams.

The retention profile of mercury (II) in aqueous solution was subjected to Freundlich ${ }^{[21]}$ isotherm model over a wide range of equilibrium concentrations. Based on the kinetic consideration the familiar Freundlich sorption isotherm is expressed in the linear form ${ }^{[21]}$ as follows:

$$
\log \mathrm{C}_{\mathrm{ads}}=\log \mathrm{A}+1 / \mathrm{n} \log \mathrm{C}_{\mathrm{e}}
$$

where, where, $\mathrm{C}_{\mathrm{e}}$ is the equilibrium concentration $\left(\mathrm{mmol} \mathrm{L}^{-1}\right)$ of mercury (II) in solution and $\mathrm{C}_{\mathrm{ads}}$ is the adsorbed mercury (II) concentration onto the used sorbents per unit mass of sorbent at equilibrium $\left(\mathrm{mol} \mathrm{g}^{-1}\right)$. A and $1 / \mathrm{n}$ are Freundlich parameters related to the maximum sorption capacity of solute $\left(\mathrm{mol} \mathrm{g}^{-1}\right)$. The plots of $\log \mathrm{C}_{\mathrm{ads}}$ versus $\log \mathrm{C}_{\mathrm{e}}$ are linear over the entire range of mercury (II) concentrations in the aqueous phase. The results are shown in Fig. 4-6 and the values of A and 1/n, computed from the intercepts and slopes of the plots, are given in Table 3. The values of $1 / \mathrm{n}<1$ indicate that, the sorption capacity is slightly reduced at lower equilibrium concentration and the isotherm does not predict any saturation of the solid surface of the adsorbent by the adsorbate. Therefore, infinite surface coverage is predicted mathematically and physico-sorption on the surface is expected. 

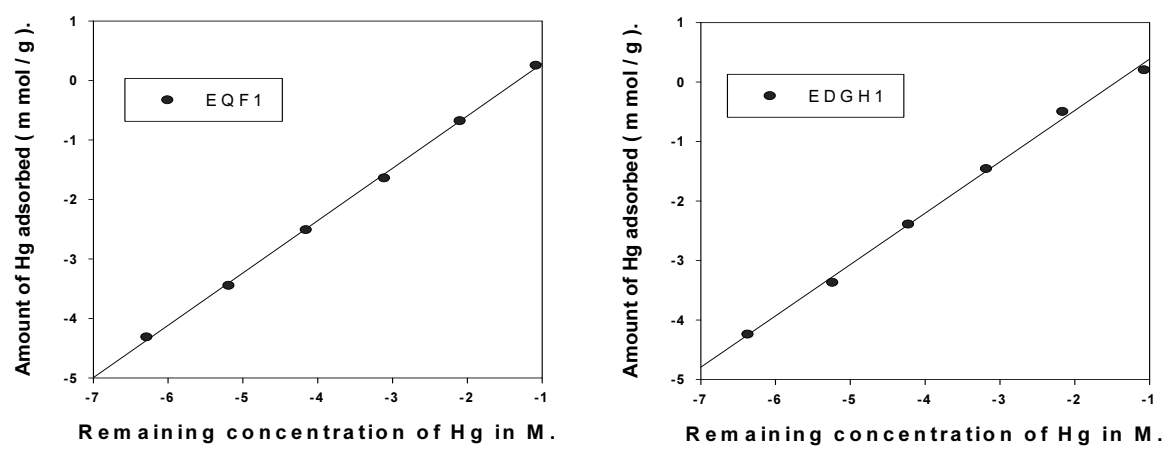

Fig. 4. Freundlich plots of adsorption of mercury (II) retention from the aqueous solution by soil samples from East region.
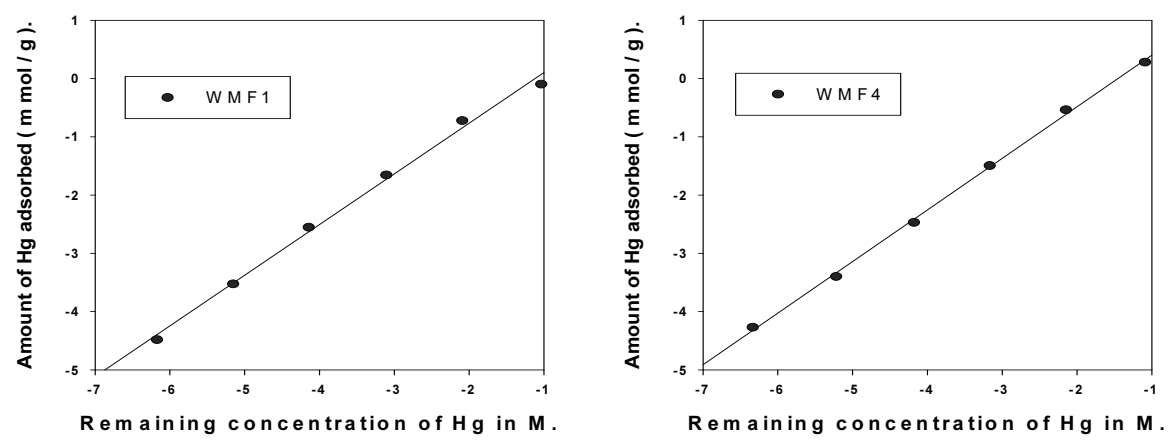

Fig. 5. Freundlich plots of adsorption of mercury (II) retention from the aqueous solution by soil samples from West region.
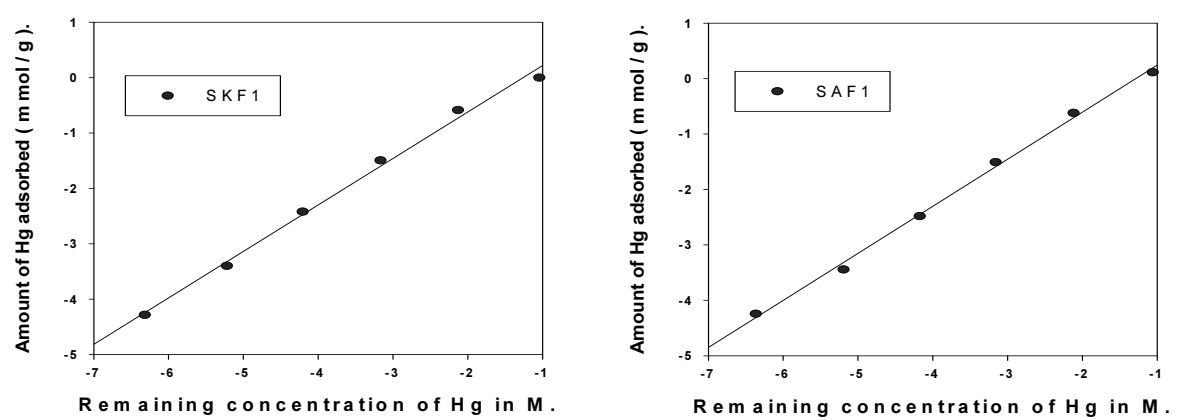

Fig. 6. Freundlich plots of adsorption of mercury (II) retention from the aqueous solution by soil samples from South region. 
Table 3. Values of slope, intercept and correlation coefficient of adsorption of $\mathrm{Hg}$ different concentrations on soil samples.

\begin{tabular}{|l|c|c|c|c|c|c|}
\hline \multicolumn{1}{|c|}{ Sample } & EQF1 & EDGH1 & WMF1 & WMF4 & SKF1 & SAF1 \\
\hline Slope & 0.8797 & 0.8691 & 0.8628 & 0.8851 & 0.8388 & 0.8488 \\
\hline Intercept & 1.1645 & 0.9720 & 1.2478 & 1.2859 & 1.0583 & 1.0923 \\
\hline $\begin{array}{l}\text { Correlation } \\
\text { coefficient }\end{array}$ & 0.9992 & 0.9955 & 0.9972 & 0.9988 & 0.9945 & 0.9970 \\
\hline
\end{tabular}

\section{Conclusion}

The proposed local solid soils represent low cost solid extractor for the separation and/or minimization of trace and ultra trace concentrations of inorganic mercury (II) ions in industrial wastewater. The used solid adsorbents could be packed in for complete separation of mercury from the aqueous solutions. The developed method of separation does not require transport bulky water samples into the laboratory for analysis, since pre-concentration can easily be made on the spot. The developed method can be optimized for the pre concentration of the analyte for the flow analysis measurements. Future work is continuing for the chemical speciation of organic and inorganic mercury species and some other toxic metal ions in the environmental samples.

\section{References}

[1] Saracoglu, S. and Elci, L., Anal. Chim. Acta., 472: 77 (2002).

[2] Lopez-Garcia, I., Merino, B.M., Campillo, N. and Cordoba, M.H., Anal. Bioanal. Chem., 373: 98 (2002).

[3] Maltez, H.F. and Carasek, E., Talanta, 65: 537 (2005).

[4] Sperling, M., Yin, X. and Welz, B., Analyst, 117: 629 (1992).

[5] Orescanin, V., Mikelic, L., Lulic, S. and Rubcic, M., Anal. Chim. Acta., 527 (2): 125 (2004).

[6] Milacic, R., Scancar, J. and Tusek, J., Anal. Bioanal. Chem., 372: 549 (2002).

[7] Sahayan, A.C., Anal. Bioanal. Chem., 372: 840 (2002).

[8] Bruhn, C.G.B., Pino, F.E., Campos, V.H. and Nobrega, J.A., Anal. Bioanal. Chem., 374: 131 (2002).

[9] Gil, R.A., Cerutti, S., Gasquez, J.A., Olsina, R.A. and Martinez, L.D., Talanta, 68: 1065 (2006).

[10] Braun, T., Navratil, J.D. and Farag, A.B., Polyurethane Foam Sorbents in Separation Science, CRC Press. Inc, FL, Boca Raton, (1985).

[11] Garcia, M.J.M., Moreno, G.S., Garcia, J.J.M., Moreno, J., Bayo, J., Perez, J.J.G. and Clavel, M., J. Water, Air and Soil Pollution, 131: 329-347 (2001).

[12] Alloway, B.J., In Alloway, B.J. (edn.), Heavy Metals in Soil, Blackie Academic and Professional, London, UK, 11 (1995). 
[13] Gasser, M.S., Arab J. Nuclr Sci. and Appl., 37(2): 23 (2004).

[14] Spinti, M., Zhuang, H. and Trujillo, E.M., Water Environ. Res., 67(6): 943 (1995).

[15] Nelson, F., Phillips, H.O. and Kraus, K.A., Eng. Bull Ext. Ser., 145: 1076 (1974).

[16] Sen, A.K. and De, A.K., Water Res., 21: 885 (1987).

[17] Kim, B.T., Lee, H.K., Moon, H. and Lee, K., J. Sep. Sci. Technol., 30(16): 3165 (1995).

[18] Amin, A.S. and Mohamed, T., Annali di Chim. Soc. Chim. Italiana, 90(5-6): 389 (2000).

[19] Solomon, A.K., Mineral Metabolism, Academic Press Inc., New York, 1: 119 (1960).

[20] Mahmoud, K.A., Abdel Fattah, A.T., Hanna, A.N., Mietry, E. and Shafic, A., Annual Report, IAEA, RES. Contr., 426: 42 Vienna (1970).

[21] Freundlich, H., Colloidal Capillary Chemistry, Methuen, London, (1926). 


\section{السلوك الاستبقائي لأيونات الزئبق الثثائي من المحاليل المائية على عينات محلية من التزبة كصنف ثابت}

خيرية محمد الأحمري و مفيدة وهبة عيسى

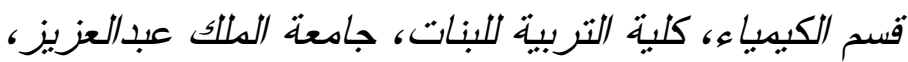

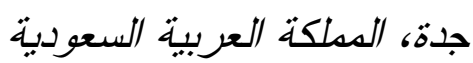

*"قسم الوقاية الإثعاعية، مركز البحوث النووية، القاهرة، دصر لعردية

\section{khairiaalahmary@yahoo.com}

الهستخلص. تمت دراسة ادمصاص الزئبق على سطح عينات مختلفة من التزبة نم جمعها من ثلاث مناطق من المملكة العربية

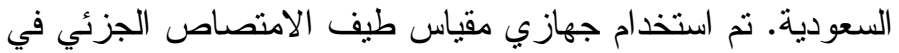

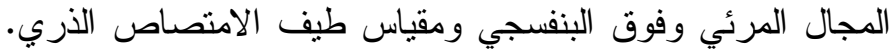

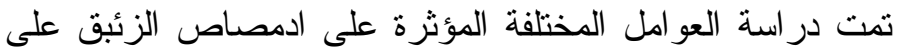

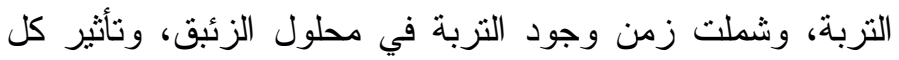

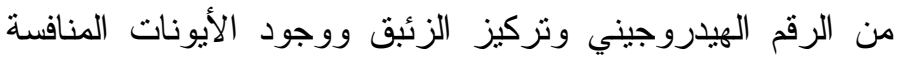
على ادمصاص الزئبق على النزبة.

دلت النتائج على أنه كلما زاد زمن بقاء التزبة في محلول

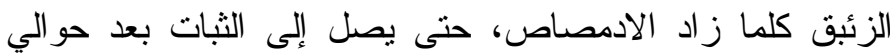

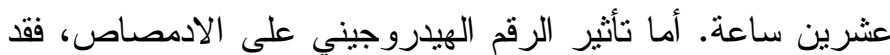

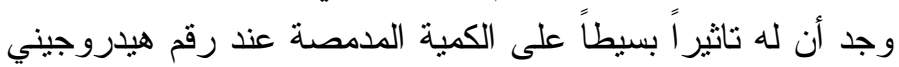

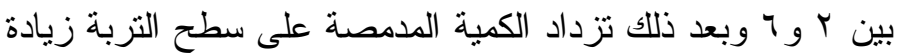

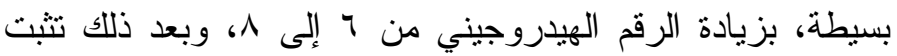

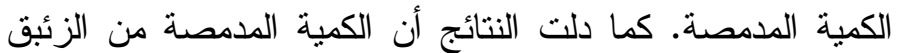

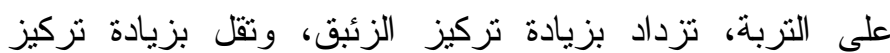

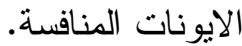

